\title{
On the systematic position of Collyricloides massanae Vaucher, 1969 (Platyhelminthes: Digenea) with notes on distribution of this trematode species
}

\author{
Gerard Kanarek • Grzegorz Zaleśny • \\ Agnieszka Czujkowska • Jiljí Sitko • Philip D. Harris
}

Received: 12 December 2014 / Accepted: 20 January 2015 / Published online: 1 February 2015

(C) The Author(s) 2015. This article is published with open access at Springerlink.com

\begin{abstract}
The systematic position of the Collyricloides massanae, a rare cyst-dwelling parasite, located on intestinal wall of European birds and rodents, have always been controversial. Based on newly obtained sequences of the 28 sDNA of C. massanae from avian and rodent host from Central Europe, and on the previously published sequences of several genera and families among Microphalloidea, we evaluate its taxonomic position and the phylogenetic relationships within the genera Collyriclum Kossack, 1911 and Collyricloides Vaucher, 1969 which form the family Collyriclidae Ward, 1917. In the cladogram, C. massanae appears among the Pleurogenidae, forming a clade with Gyrabascus amphoraeformis (Modlinger, 1930) and Cortrema magnicaudata (Bykhovskaya-Pavlovskaya, 1950). We reject the commonly accepted placement of Collyricloides as the sister genus to Collyriclum within the Collyriclidae. Besides, we present and discuss the unusual records of $C$. massanae in the bank vole Myodes glareolus from northeastern Poland.
\end{abstract}

\author{
G. Kanarek $(\bowtie)$ \\ Ornithological Station, Museum and Institute of Zoology, Polish \\ Academy of Sciences, ul. Nadwiślańska 108, 80-680 Gdańsk, Poland \\ e-mail:kanarek@miiz.waw.pl \\ G. Zaleśny \\ Institute of Biology, Wrocław University of Environmental and Life \\ Sciences, ul. Kożuchowska 5b, 51-631 Wrocław, Poland \\ A. Czujkowska \\ Warsaw Zoological Garden, ul. Ratuszowa 1/3, \\ 03-461 Warszawa, Poland \\ J. Sitko \\ Comenius Museum, Horní nám. 7, 75011 Přerov, Czech Republic \\ P. D. Harris \\ Natural History Museum, University of Oslo, P.O. Box 1172, \\ N-0562 Oslo, Norway
}

Keywords Trematoda $\cdot$ Microphalloidea $\cdot$ Collyriclidae . Collyricloides $\cdot$ Molecular phylogeny

\section{Introduction}

The digenean Collyriclum faba is a moderately well-known parasite found in subcutaneous tissue cysts in a variety of bird species. The systematic position of this parasite has been doubtful for many years: Odhner (1914) placed the genus in his family Troglotrematidae, while Ward (1917) regarding the isolated position of Collyriclum among monostomes, created the new family Collyriclidae Ward, 1917. Validity of the family was confirmed by Harrah (1922), but many authors of this period (e.g., Baer 1932; Witenberg 1932; Wallace 1935) continued to include Collyriclum within the family Troglotrematidae. The Troglotrematide proposed by Odhner (1914) was redefined by Dollfus (1939), leaving Collyriclum as the only genus within the Collyriclidae, a family placed within the superfamily Troglotrematoidea by Yamaguti (1971). In the latest classification based exclusively on morphological criteria, the Collyriclidae was included within the superfamily Gorgoderoidea Loss, 1899 and consists of two monotypic genera Collyriclum Kossack, 1911 and Collyricloides Vaucher, 1969 (Blair and Barton 2008); the latter erected to accommodate a digenean from rodents which lives in internal cysts and strongly resembles $C$. $f a b a$, but which possesses two suckers. Recently published analyses of variable $18 \mathrm{~S}$ and $28 \mathrm{~S}$ rDNA of $C$. faba have reassessed the relationships of Collyriclum and have placed it unambiguously within the Microphalloidea (Heneberg and Literák 2013; Kanarek et al. 2014).

The position of the genus Collyriclum is unquestionable, but the status of Collyricloides is much more contentious. 
Although similar to Collyriclum, Collyricloides massanae was collected from intestinal cysts in the yellow-necked mouse Apodemus flavicollis from SW France and differs especially by the possession of a ventral sucker (Vaucher 1969), but also in several important details of the arrangement of the genital- and excretory pores, the bursa cirri, the seminal receptacle and the metraterm. Based on these differences, it seems unlikely that Collyriclum and Collyricloides are closely related, but to date, there has been no question as to their membership of the Collyriclidae. We hypothesize that the resemblance between the two genera is superficial and convergent, and results from similarities in cyst-dwelling habitat, rather than being evidence of real phylogenetic affinity. In the present work, we evaluate the phylogenetic relationships of Collyriclum and Collyricloides within the family Collyriclidae, and present new data on the geographical distribution of Collyricloides.

\section{Materials and methods}

\section{Sampling protocols}

Material of digeneans from intestinal cysts were collected by dissection from a male Eurasian wren Troglodytes troglodytes, admitted to the Rehabilitation Centre for Protected Birds, Warsaw Zoological Garden which subsequently died. Necropsy revealed five large cysts on the serosal surface of the intestine; adult digeneans were isolated from the cysts, washed in tap water, fixed, and stored in $70 \%$ ethanol. Additionally, five specimens of $C$. massanae were isolated from the cysts located on the intestine of adult male of European robin Erithacus rubecula, found dead on 6 April 2014 near Zahlinice, $15 \mathrm{~km}$ to south to Přerov, Kroměřǐž District, Moravia, Czech Republic. Specimens were isolated, processed as above and identified according to original description (Vaucher 1969). Voucher specimens, stored in ethanol have been deposited in Polish Collection of Parasitic Helminths, Museum of Natural History, Wrocław, Poland, Coll. No. 144283 (specimens ex T. troglodytes) and 144284 (specimens ex E. rubecula). Further samples of C. massanae were derived from Myodes glareolus from Urwitalt forest, northeastern Poland, where the parasite has been sporadically found to occur. In this case, during fieldwork in 2008/2009, two M. glareolus (out of c. 1000 examined over 10 years) were found infected with $C$. massanae. In both cases, up to seven parasites were located in cysts attached to the intestinal wall.

DNA extraction, amplification and sequencing

Total genomic DNA was extracted from six worms (two from M. glareolus, two from T. troglodytes, and two from
E. rubecula) following the manufacturer's protocol (DNeasy Blood and Tissue Kit, Qiagen, Germany). The 28S rDNA locus was amplified using primers: forward- $\operatorname{dig} 12\left(5^{\prime}\right.$ AAG CAT ATC ACT AAG CGG-3') and reverse-1500R (5'-GCT ATC CTG AGG GAA ACT TCG-3') (Tkach et al. 2003). The ITS1-5.8S-ITS2 region was amplified with the following primers: NLF/NLR (5'-TTTGyACACACCGCC CGTCG-3'/5'-ATATGCTTAArTTCAGCGGGT-3') (Van der Auwera et al. 1994). PCR reactions were performed in a total volume of $25 \mu \mathrm{l}$ containing $3 \mu \mathrm{l}$ of genomic DNA, $10 \mathrm{mM}$ Tris- $\mathrm{HCl}, 50 \mathrm{mM} \mathrm{KCl}, 1.5 \mathrm{mM} \mathrm{MgCl} 2,200 \mu \mathrm{M}$ of each dNTP, 150 pmol of each primer, and 2 units of Taq polymerase (EurX, Poland). The thermocycling profile was as follows: $95{ }^{\circ} \mathrm{C} / 3$ min-initial denaturation; $94{ }^{\circ} \mathrm{C} / 30 \mathrm{~s}, 52{ }^{\circ} \mathrm{C} / 30 \mathrm{~s}$ (28SrDNA) or $48^{\circ} \mathrm{C} / 30 \mathrm{~s}$ (ITS complex), $72^{\circ} \mathrm{C} / 90 \mathrm{~s}-40 \mathrm{cy}-$ cles; $72{ }^{\circ} \mathrm{C} / 7 \mathrm{~min}$ - final extension.

The amplification products were purified using QIAquick PCR purification Kit (Qiagen, Germany) and sequenced in both directions (Genomed S.A., Poland). The obtained sequences were deposited in GenBank under accession numbers KP682451 and KP682452.

\section{Alignment and phylogenetic analyses}

In order to elucidate any homologies with previously deposited sequences in GenBank, we conducted a BLAST search (www.ncbi.nih.gov/BLAST). This analysis showed that the sequences of C. massanae were closest to representatives of the superfamily Microphalloidea; thus, in the alignment, we use previously published sequences of Microphalloidea (Table 1). Sequences were aligned using the MAFFT v.7 software (www.mafft.cbrc.jp/) with FFT-NS-1 option. The phylogenetic analysis was performed using Bayesian inference (BI) with the MrBayes ver. 2.01 software (Huelsenbeck and Ronquist 2001); sequences of Fasciola hepatica (AY222244) was chosen as an outgroup. Bayesian inference was employed using the following nucleotide substitution parameters: $n s t=6$, rates $=$ invgamma, that correspond to a general time reversible model (GTR) including estimates of the proportion of invariant sites (I) and gamma distribution (G). Posterior probabilities were approximated over 1,000,000 generations, log-likelihood scoters plotted and only the final $75 \%$ of trees were used to produce the consensus tree by setting the 'burnin' parameter at 250,000 . This number of generation was sufficient because the standard deviation dropped below 0.01 at the end of the run.

\section{Results}

The final alignment of the 1srDNA fragment was $1275 \mathrm{bp}$ long. The BI analysis resulted in a tree, with topology which strongly resembled the results from the previous phylogenetic 
Table 1 The list of digenean species used in this study, with the information on their hosts, GenBank accession number and reference

\begin{tabular}{|c|c|c|c|}
\hline Parasite species & Host species & Reference & $\begin{array}{l}\text { GenBank } \\
\text { accession } \\
\text { number }\end{array}$ \\
\hline Lecithodendrium linstowi & Nyctalus noctula & Tkach et al. 2003 & AF151919 \\
\hline Ophiosacculus mehelyi & Eptesicus serotinus & Tkach et al. 2003 & AF480167 \\
\hline Prosthodendrium chilostomum & Nyctalus noctula & Tkach et al. 2003 & AF151920 \\
\hline Prosthodendrium hurkovae & Myotis daubentoni & Tkach et al. 2003 & AF151922 \\
\hline Prosthodendrium longiforme & Myotis daubentoni & Tkach et al. 2003 & AF151921 \\
\hline Prosthodendrium parvouterus & Miniopterus schreibersi & Tkach et al. 2003 & AY220617 \\
\hline Pycnoporus heteroporus & Pipistrellus kuhli & Tkach et al. 2003 & AF151918 \\
\hline Pycnoporus megacotyle & Pipistrellus kuhli & Tkach et al. 2003 & AF151917 \\
\hline Gyrabascus amphoraeformis & Myotis daubentoni & Tkach et al. 2003 & AY220620 \\
\hline Brandesia turgida & Rana lessonae & Tkach et al. 2003 & AY220622 \\
\hline Candidotrema loossi & Rana ridibunda & Tkach et al. 2003 & AY220621 \\
\hline Parabascus joannae & Myotis daubentoni & Tkach et al. 2003 & AY220619 \\
\hline Parabascus duboisi & Myotis daubentoni & Tkach et al. 2003 & AY220618 \\
\hline Parabascus semisquamosus & Pipistrellus kuhli & Tkach et al. 2003 & AF151923 \\
\hline Pleurogenes claviger & Rana temporaria & Tkach et al. 2003 & AF151925 \\
\hline Pleurogenoides medians & Rana lessonae & Tkach et al. 2003 & AF433670 \\
\hline Prosotocus confusus & Rana lessonae & Tkach et al. 2003 & AY220623 \\
\hline Prosthogonimus cuneatus & Sturnus vulgaris & Tkach et al. 2003 & AY220634 \\
\hline Prosthogonimus ovatus & Pica pica & Tkach et al. 2003 & AF151928 \\
\hline Prosthogonimus rarus & Anas querquedula & Tkach et al. 2003 & AY116869 \\
\hline Cortrema magnicaudata & Hirudo rustica & Kanarek et al. 2014 & KJ700420 \\
\hline Collyriclum faba & Sturnus vulgaris & Heneberg and Literák 2013 & JQ231122 \\
\hline Collyricloides massanae & Erithacus rubecula & This study & KP682451 \\
\hline Maritrema heardi & Oryzomys palustris & Tkach et al. 2003 & AY220632 \\
\hline Maritrema neomi & Neomys anomalus & Tkach et al. 2003 & AF151927 \\
\hline Maritrema oocysta & Hydrobia ulvae & Tkach et al. 2003 & AY220630 \\
\hline Maritrema arenaria & Cirripedia & Tkach et al. 2003 & AY220629 \\
\hline Maritrema prosthometra & Oryzomys palustris & Tkach et al. 2003 & AY220631 \\
\hline Maritrema subdolum & Tringa erythropus & Tkach et al. 2003 & AF151926 \\
\hline Microphallus similis & Carcinus maenas & Tkach et al. 2003 & AY220625 \\
\hline Microphallus triangulatus & Somateria mollissima & Galaktionov et al. 2012 & HM584139 \\
\hline Microphallus basodactylophallus & Oryzomys palustris & Tkach et al. 2003 & AY220628 \\
\hline Microphallus abortivus & Hydrobia ulvae & Tkach et al. 2003 & AY220626 \\
\hline Microphallus primas & Hydrobia ulvae & Tkach et al. 2003 & AY220627 \\
\hline
\end{tabular}

study of Microphalloidea by Kanarek et al. (2014), except C. massanae, lacking in cited work. As in previous works, families Pleurogenidae, Prosthogonimidae and Collyriclidae formed $100 \%$ supported clade, confirmed status of Collyriclidae as independent family within Microphalloidea (Fig. 1). C. massanae appeared amongst the Pleurogenidae and is closest to Gyrabascus amphoraeformis (Modlinger, 1930) (parasites of bats) and Cortrema magnicaudata (Bykhovskaya-Pavlovskaya, 1950) (parasites of birds). However, the clade uniting genera Gyrabascus and Cortrema is relatively weakly supported $(65 \%)$ which suggests that these genera may represent separate phylogenetic lineages. Collyricloides, Cortrema and Gyrabascus with three species from the genus Parabascus Looss, 1907 (parasites of bats) forming clade among Pleurogenidae uniting genera typical for warmblooded animals. Sister branch of Pleurogenidae forming species characteristic from amphibians (genera Brandesia Stossich, 1899; Candidotrema Dollfus, 1951; Pleurogenes Looss, 1896; Pleurogenoides Travassos, 1921 and Prosotocus Looss, 1899).

Additionally, as result of molecular analysis, we have obtained ITS complex sequences (ITS1, ITS2 and 5.8S rDNA) of $C$. massanae derived from three different host species. 


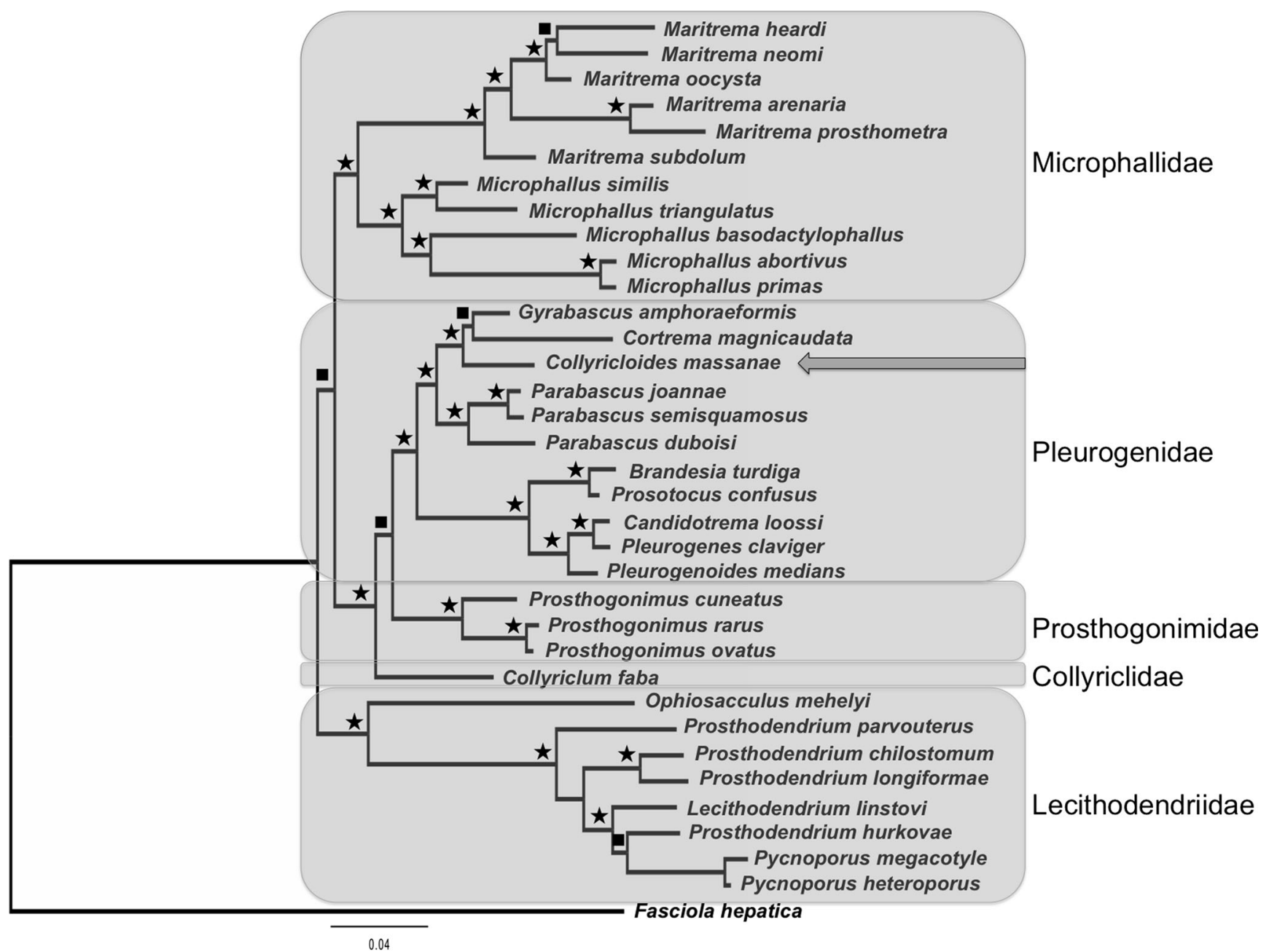

Fig. 1 The phylogram resulting from Bayesian analysis of partial sequences of $28 \mathrm{~S}$ rDNA gene. Posterior probabilities are expressed by the use of symbols: star (>90\% posterior probabilities) and filled square

However, we did not observe the intraspecific variation in this region.

\section{Discussion}

The present lsrDNA sequences-based phylogenetic analysis has demonstrated that genus Collyricloides belongs to the family Pleurogenidae within the superfamily Microphalloidea. Thus, the conventional view of Collyricloides as a sister genus to Collyriclum within the family Collyriclidae, held since the description of the genus by Vaucher (1969) and confirmed in the latest taxonomic arrangement of Blair and Barton (2008), is emphatically rejected. Based on molecular evidence, Collyricloides appears closest to bat and bird parasites Gyrabascus Macy, 1935 and Cortrema Tang, 1951, but remarkably, these three genera share few morphological features: only the pre-testicular
( $>60 \%$ posteriori probabilities). The arrow indicates the position of Collyricloides massanae

ovary, the I-shaped excretory vesicle, a post- acetabular genital pore, and pre-acetabular vitellaria are common to all three. Both Gyrabascus and Collyricloides have virgulated xiphidocercariae developing in prosobranch snails (Burns 1961a and b; Schwarz 1981), but data regarding cercarial morphology of Cortrema (non-virgulated xiphidocercariae in pulmonate snails according to Tang and Tang (1981)) should be treated with caution (for details see Kanarek et al. 2014). Unlike Cortrema and Gyrabascus, which both lack a cirrussac and a visible pars prostatica and have a long, coiled seminal vesicle lying freely in parenchyma, Collyricloides possesses a well-developed cirrus-sac containing an internal seminal vesicle and a visible pars prostatica. Both Collyricloides and Cortrema possess a long Laurer's canal, a seminal receptaculum, and long caeca, characters not seen in Gyrabascus. However, Schwarz (1981) contests the occurrence of bursa cirri in C. massanae ("Das Vas deferens führt $\mathrm{zu}$ einem kleinem schwach entwickeln Cirrus: ein Cirrusbeutel fehlt"), a detail noted in the original description 
(Vaucher 1969). Schwarz (1981) appears to have analysed morphology and anatomy of C. massanae without sectioning; in adult, whole mounts of this species, almost the entire body, is filled with eggs and anatomical details are almost impossible to discern. To sum up, the morphology of Collyricloides, Cortrema, and Gyrabascus is divergent, and while it is possible that these genera belong to different lineages amongst the Pleurogenidae, it is unambiguous that they are all pleurogenids and that Collyricloides is not part of the Collyriclidae.

At the same time that Collyricloides shows strong morphological differentiation from its closest relatives in the Pleurogenidae, it shows remarkable convergence with the morphology of Collyriclum faba from the unrelated Collyriclidae. This convergence has certainly confused most researchers who have compared these worms, including Vaucher (1969), who clearly believed the two forms to be closely related. The only characters noted as separating Collyricloides from Collyriclum were the differences in sucker number and differences in structure of the metraterm. However, as noted above, comparison of whole mounts is almost impossible because the eggs obscure all internal anatomy, and sections of the two forms have not been compared. The convergence is presumably due to the cyst-dwelling life style of both species, with numerous individuals living together within the cyst.

Another interesting issue concerns the geographical distribution of $C$. massanae and their host specificity. Natural infections of $C$. massanae have been detected several times in rodents (Jourdane and Triquell 1973; Mas-Coma and Feliu 1977; Schwarz 1981; Ribas et al. 2005) and in passeriform birds (Borgsteede and Smit 1980; Schwarz 1981; Sitko et al. 2006; Okulewicz et al. 2010) in Europe. C. faba has been recorded in a wide range of birds (mainly Passeriformes, but also Anseriformes, Galliformes, Charadriiformes, Coraciiformes, Piciformes) in Europe, Asia and Americas (for review see e.g., Bykhovskaya-Pavlovskaya and Khotenovskiı̌ 1964; Stunkard 1971; Literák et al. 2003; Literák and Sitko 2006; Heneberg et al. 2011; Literák et al. 2011). All previous records of $C$. massanae in rodents (Apodemus flavicollis, A. sylvaticus) have been limited to mountainous areas of central (Schwarzwald) and southern (Pyrenees) Europe, while the occurrence of C. massanae in sedentary and short distance migrant birds (Sturnus vulgaris, Sitta europea, Certhia familiaris, Turdus merula) is mainly confined to northern Europe (see references above). Birds are much more mobile than rodents, and even for the sedentary or short distance migrants noted as hosts of C. massanae, migrations of several hundred kilometres are not extraordinary. Rodents, on the other hand, tend to have home ranges of a few hundred (rarely thousands) square meters (e.g., Kozakiewicz et al. 2007), and their helminth fauna predicts local ecological conditions. The life cycle of $C$. massanae can be assumed to be closely related with ecological conditions in mountainous areas of central and southern Europe, whereas findings in birds in Europe are more directly related to migratory behaviour. In this respect, the occurrence of $C$. massanae in Myodes graeolus from northern Poland is a complete surprise: this is the furthest north that this digenean has been found, some $1000 \mathrm{~km}$ north of all previous records. According to Schwarz (1981), the first intermediate host for C. massanae is the snail Bythinella dunkeri; invasive stages occur in insects which are related to stream ecosystems (Ephemeroptera, Plecoptera and Trichoptera). The genus Bythinella Moquin-Tandon, 1856 is distributed from the Iberian Peninsula to west Asia, and inhabit fast-flowing, cold, well-oxygenated waters and hypogean habitats (e.g., Falniowski et al. 1998). All species are alpine elements and glacial relicts (Falniowski 1987). Only a small number of about 90 described Bythinella species and subspecies (Prié and Bichain 2009) have been recorded from Poland, with their distribution limited to the southern parts of the country: B. austriaca, B. cylindrica, B. zyvionteki, B. metarubra, and B. micherdzinskii (Falniowski 1987). However, contemporary taxonomy of Bythinella is extremely complex with several controversies concerning the species distinctness (e.g., Bichain et al. 2007; Benke et al. 2011; Falniowski et al. 2012). In fact, it is impossible to distinguish the species without molecular analyses, consequently, the genus is often regarded as superspecies (Falniowski et al. 1998). At first sight, the Urwitałt forest represents an unpromising habitat for these snails, being an extensive, flat, cold, managed pine and birch forest dating to at least the early nineteenth century (Paziewska et al. 2010) and growing on sand and clay soils. However, Bithyniella is relatively resistant to desiccation and can be amphibious in behaviour (Falniowski 1987; Falniowski et al. 1998), and some isolated populations may exist within the Masurian Lakeland, rich in lakes and water courses with relatively cold and well-oxygenated water. In fact, the sample areas where the parasite was found in Urwitałt can flood in winter, and from one of the localities where Collyricloides was found, Notocotylus sp. was also found in Myodes, suggesting that the voles do have a semiamphibious life style at some times of the year. The description of Notocotylus malhami from bank voles (Boyce et al. 2012) also indicates that this rodent can have a close relationship with amphibious molluscs in boggy or waterlogged ground. Nevertheless, it must be stressed that $C$. massanae was extremely rare at Urwitałt; this is the field site of the University of Warsaw/University of Nottingham long-term study of stability in bank vole helminth communities (Behnke et al. 2008a and b), and yet, the parasite has never been found in those surveys. At the same time, the parasite is cryptic; the cysts resemble extraneous pancreatic tissue and can be easily missed during dissection of freshly killed hosts, and so, it is possible that this digenean is actually much 
commoner in Europe than the existing records suggest. We also cannot exclude the possibility that the specificity of C. massanae to the snail intermediate hosts may be much broader than suggested by Schwarz (1981). These interesting issues will be examined in the forthcoming publications.

Conflict of interest The authors declare that they have no conflict of interest.

Ethical approval All applicable international, national, and institutional guidelines for the care and use of animals were followed.

Open AccessThis article is distributed under the terms of the Creative Commons Attribution License which permits any use, distribution, and reproduction in any medium, provided the original author(s) and the source are credited.

\section{References}

Baer J-G (1932) Contribution á la Faune helminthologique de Suisse (Deuxième partie). Rev Suisse Zool 39:1-57

Behnke JM, Bajer A, Harris PD, Newington L, Pidgeon E, Rowlands G, Sheriff C, Kuliś-Malkowska K, Siński E, Gilbert FS, Barnard CJ (2008a) Temporal and between-site variation in helminth communities of bank voles (Myodes glareolus) from N. E. Poland. 1. Regional fauna and component community levels. Parasitology 135:985-997. doi:10.1017/S0031182008004393

Behnke JM, Bajer A, Harris PD, Newington L, Pidgeon E, Rowlands G, Sheriff C, Kuliś-Malkowska K, Siński E, Gilbert FS, Barnard CJ (2008b) Temporal and between-site variation in helminth communities of bank voles (Myodes glareolus) from N. E. Poland. 2. The infracommunity level. Parasitology 135:999-1018. doi:10.1017/ S0031182008004484

Benke M, Brändle M, Albrecht C, Wilke T (2011) Patterns of freshwater biodiversity in Europe: lessons from the spring snail genus Bithyniella. J Biogeogr 38:2021-2032. doi:10.1111/j.1365-2699. 2011.02527.x

Bichain J-M, Gaubert P, Samadi S, Boisselier-Daubyle M-C (2007) A gleam in the dark: phylogenetic species delimitation in the confusing spring-snail genus Bythinella Moquin-Tandon, 1856 (Gastropoda: Rissooidea: Amnicolidae). Mol Phylogenet Evol 45:927-941. doi: 10.1016/j.ympev.2007.07.018

Blair D, Barton DP (2008) Family Collyriclidae Ward, 1917. In: Bray $\mathrm{RD}$, Gibson DI, Jones A (eds) Keys to the Trematoda volume 3. CAB International and Natural History Museum, London, pp 227230

Borgsteede FHM, Smit TH (1980) Collyricloides massanae Vaucher, 1969, in a starling (Sturnus vulgaris L.) in the Netherlands. J Helminthol 54:93-95. doi:10.1017/S0022149X00006416

Boyce K, Hide G, Craig PS, Harris PD, Reynolds C, Pickles A, Rogan MT (2012) Identification of a new species of digenean Notocotylus malhamensis n. sp. (Digenea: Notocotylidae) from bank vole (Myodes glareolus) and the field vole (Microtus agrestis). Parasitology 139:630-1639. doi:10.1017/S0031182012000911

Burns WC (1961a) Six virgulate xiphidiocercariae from Oregon, including redescriptions of Allassogonoporus vespertilionis and Acanthatrium oregonense. J Parasitol 47:919-925

Burns WC (1961b) Penetration and development of Allassogonoporus vespertilionis and Acanthatrium oregonense (Trematoda:
Lecithodendriidae) cercariae in caddis fly larvae. J Parasitol 47: 927-932

Bykhovskaya-Pavlovskaya IE, Khotenovskiū IA (1964) On the morphology of the trematode Collyriclum faba (Bremser, 1831). Parasitol Sb 22:207-219

Dollfus R-P (1939) Distome d'un abcès palpébro-orbitaire chez une panthére. Possibilité d'affinités lointaines entre ce distome et les Paragonimidae. Ann Parasitol 17:209-235

Falniowski A (1987) Hydrobioidea of Poland (Prosobranchia: Gastropoda). Folia Malacol 1:1-122

Falniowski A, Szarowska M, Fiałkowski W, Mazan K (1998) Unusual geographic pattern in interpopulation variation in a spring snail Bythinella (Gastropoda: Prosobranchia). J Nat Hist 32:605-616. doi:10.1080/00222939800770311

Falniowski A, Szarowska M, Glöer P, Pešić V, Georgiev D, Horsák M, Sibru I (2012) Radiation in Bythinella Moquin-Tandon, 1856 (Mollusca: Gastropoda: Rissooidea) in the Balkans. Folia Malacol 20:1-10. doi:10.2478/v10125-012-0006-2

Galaktionov KV, Blasco-Costa I, Olson P (2012) Life cycles, molecular phylogeny and historical biogeography of the 'pygmaeus' microphallids (Digenea: Microphallidae): widespread parasites of marine and coastal birds in the Holarctic. Parasitology 139:1346 1360. doi:10.1017/S0031182012000583

Harrah EC (1922) North American monostomes primarily from fresh water hosts. Ill Biol Monogr 7:221-324

Heneberg P, Literák I (2013) Molecular phylogenetic characterization of Collyriclum faba with reference to its three host-specific ecotypes. Parasitol Int 62:262-267. doi:10.1016/j.parint.2013.01.002

Huelsenbeck JP, Ronquist F (2001) MrBayes: Bayesian inference of phylogeny. Bioinformatics 17:754-755. doi:10.1093/bioinformatics/17. 8.754

Jourdane J, Triquell A (1973) Digènes parasites d'Apodemus sylvaticus (L.) dans la partie orientale des Pyrénées. Description de Macyella apodemi sp. n. Bull Mus Natl Hist Nat 117:351-361

Kanarek G, Zaleśny G, Sitko J, Tkach V (2014) Phylogenetic relationships and systematic position of the families Cortrematidae and Phaneropsolidae (Platyhelminthes: Digenea). Folia Parasitol 61: 523-528. doi:10.14411/fp.2014.057

Kozakiewicz M, Chołuj A, Kozakiewicz A (2007) Long-distance movements of individuals in a free-living bank vole population: an important element of male breeding strategy. Acta Theriol 52:339-348. doi:10.1007/BF03194231

Literák I, Honza M, Haluzík M, Haman A, Pinowska B, Pčola Š (2003) Cutaneous trematode Collyriclum faba in wild birds in the Central Europe Carpathians. J Parasitol 89:412-416. doi:10.1645/00223395(2003)089[0412:CTCFIW]2.0.CO;2

Literák I, Sitko J (2006) Where in Europe should we look for sources of the cutaneous trematode Collyriclum faba infections in migrating birds? J Helminthol 80:349-355. doi:10.1017/JOH2006362

Literák I, Sitko J, Sychra O, Čapek M (2011) Cutaneous trematode Collyriclum faba in wild birds in Costa Rica. Helminthologia 48: 288-289

Mas-Coma S, Feliu C (1977) Contribucion al conacimiento de la helmintofauna de macromamiferos Ibericos. IV. Parasitos de Apodemus sylvaticus Linnaeus, 1758 (Rodentia: Muridae). Rev Ibér Parasitol 37:301-317

Odhner T (1914) Die Verwandtschaftsbeziehungen der Trematodengattung Paragonimus Brn. Zool Bidr Upps 3:231-246

Okulewicz A, Okulewicz J, Sitko J, Wesołowska M (2010) New records of digenean flukes (Trematoda) in birds in Poland. Wiad Parazytol 56:67-70

Paziewska A, Zwolińska L, Harris PD, Bajer A, Siński E (2010) Utilisation of rodent species by larvae and nymphs of hard ticks (Ixodidae) in two habitats in NE Poland. Exp Appl Acarol 50:7991. doi:10.1007/s10493-009-9269-8 
Prié V, Bichain J-M (2009) Phylogenetic relationships and description of a new stygobite species of Bithyniella (Mollusca, Gastropoda, Caenogastropoda, Amnicolidae) from southern France. Zoosystema 31:987-1000. doi:10.5252/z2009n4a12

Ribas A, Casanova JC, Miquel J, Fons R, Giusset C, Feliu C (2005) On the fauna of digenetic trematodes, parasites of small mammals, in the natural reserves of Py and Mantet (Oriental Pyrenees, France). Helminthologia 42:71-75

Schwarz J (1981) Über den Lebenszyklus des Trematoden Collyricloides massanae Vaucher 1969 (Trematoda: Collyrididae) und seine Entwicklungsstadien. Beitr Naturkde Osthessen 17:85-99

Sitko J, Faltýnková A, Scholz T (2006) Checklist of the trematodes (Digenea) of birds of the Czech and Slovak Republics. Academia, Praha

Stunkard HW (1971) The occurrence and distribution of the digenetic trematode Collyriclum faba (Bremser in Schmalz, 1831). J Parasitol 57:682-683

Tang CC, Tang ZZ (1981) Studies on the life cycle of Cortrema corti Tang. Acta Zool Sin 27:64-74
Tkach VV, Littlewood DTJ, Olson PD, Kinsella JM, Świderski Z (2003) Molecular phylogenetic analysis of the Microphalloidea Ward, 1901. Syst Parasitol 56:1-15

Van der Auwera G, Chapelle S, de Wachter R (1994) Structure of the large ribosomal subunit RNA of Phytophtora megasperma, and phylogeny of the oomycetes. FEBS Letters 338:133-136. doi:10. 1016/0014-5793(94)80350-1

Vaucher C (1969) Collyricloides massanae n. gen. n. sp. (Collyriclidae) trématode vivant dans kystes de l'intestin du mulot Apodemus flavicollis (Melchior). Vie et Milieu 20:29-39

Wallace FG (1935) A morphological and biological study of the trematode Sellacotyle mustelae n.g., n.sp. J Parasitol 21:143-166

Ward HB (1917) On the structure and classification of North American parasitic worms. J Parasitol 4:1-13

Witenberg G (1932) On anatomy and systematic position of the causative agent of so-called salmon poisoning. J Parasitol 18:258-263

Yamaguti S (1971) Synopsis of digenetic trematodes of vertebrates, vol I. Keigaku Publishing, Tokyo 